\title{
UPAYA MENINGKATKAN HASIL BELAJAR ILMU PENGETAHUAN SOSIAL MELALUI METODE PEMBELAJARAN WORD SQUARE PADA SISWA KELAS VI SD NEGERI 163087 TEBING TINGGI
}

\author{
Syahrial Nasty \\ Surel: nastysyahrial@gmail.com
}

\begin{abstract}
The types of this research is classroom action research, there are 2 cycles in this research with four phases: planning, implementation, observation, reflection.The locaton of this research at SDN 163087 Tebing Tinggi. This research aim to describe this increase in teacher activity, student activity, and improvement of student learning result in social studies by appliying Word Square learning method. The subject of research is teacher and student third grader which amounted to 32 students. This study used a qualitative descriptive analysis technique. The result obtained from the learning results in the first cycle is $75 \%$ has increased in two cycle get 90,62\% and students activity in cycle I is 77, 4\% has increased in cycle II get $81,2 \%$. From the data obtained can be concluded that the word square learning model can improve students learning outcomes in class VI SDN 163087 Tebing Tinggi.
\end{abstract}

Keywords: Word Square, IPS, Qualitative Descriptive

\begin{abstract}
ABSTRAK
Jenis penelitian ini adalah penelitian tindakan kelas, penelitian dilakukan sebanyak 2 siklus dengan empat tahapan yaitu: perencanaan, pelaksanaan, observasi, refleksi. Lokasi penelitian di SDN 163087 Tebing Tinggi. Penelitian ini bertujuan untuk mendeskripsikan peningkatan aktivitas guru, aktivitas siswa, dan hasil belajar pada mata pelajaran IPS dengan menerapkan metode pembelajaran Word Square. Subjek penelitiannya adalah guru dan siswa kelas VI sebanyak 32 siswa. Penelitian ini menggunakan teknik analisis dekriptif kualitatif. Hasil yang didapatkan dari penelitian yang telah dilakukan diperoleh ketuntasan belajar siklus I adalah $75 \%$, pada siklus II 90,62\% dan aktivitas siswa pada siklus I adalah $77,4 \%$, pada siklus II $81,2 \%$. Dari data yang diperoleh dapat diambil kesimpulan bahwa model pembelajaran Word Square dapat meningkatkan hasil belajar siswa kelas VI SDN 163087 Tebing Tinggi.
\end{abstract}

Kata Kunci: Word Square, IPS, Dekriptif Kualitatif

\section{PENDAHULUAN}

Ilmu Pengetahuan Sosial adalah ilmu pengetahuan yang mengkaji berbagai disiplin ilmu sosial dan humaniora serta kegiatan dasar manusia yang dikemas secara ilmiah dalam rangka memberi wawasan dan pemahaman yang mendalam kepada peserta didik, khususnya di tingkat dasar dan menengah. Luasnya kajian IPS ini mencakup berbagai kehidupan sosial, ekonomi, psikologi, budaya, sejarah maupun politik, semuanya dipelajari dalam ilmu sosial ini (Susanto, 2013 : 137).

Peserta didik merupakan manusia yang hidup di tengah-tengah masyarakat. Untuk dapat hidup 
harmonis di masyarakat harus memiliki bekal pengetahuan dan ketrampilan dalam berinteraksi dengan manusia yang lain. Manusia harus saling menghormati, saling menghargai serta sadar akan hak dan kewajibannya sebagai anggota masyarakat. Hal tersebut merupakan salah satu alasan pentingnya IPS diajarkan di Sekolah Dasar, sesuai dengan tujuan pendidikan IPS di SD yaitu untuk mempersiapkan peserta didik menjadi warga negara yang menguasai pengetahuan (knowledges), keterampilan (skills), sikap dan nilai (attitudes and values) yang dapat digunakan sebagai kemampuan untuk memecahkan masalah pribadi/ masalah sosial serta kemampuan mengambil keputusan dan berpartisipasi dalam berbagai kegiatan kemasyarakatan agar menjadi warga negara yang baik (Sapriya, 2009:12).

Kenyataan menunjukan bahwa pelaksanaan proses belajar mengajar disekolah sebagian besar masih dilakukan secara konvensional. Di SDN 163087 Tebing Tinggi khususnya kelas VI, hasil belajar mata pelajaran IPS masih rendah yaitu di bawah KKM atau di bawah 70. Hasil ulangan harian I IPS kelas VI yang berjumlah 32 siswa adalah: 15 siswa memperoleh nilai di bawah KKM dan 17 siswa memperoleh nilai KKM dan di atas KKM. Hal ini disebabkan karena materi pelajaran IPS di kelas V dianggap sulit, banyak hafalan, materinya terlalu banyak dan cara penyampaian materinya pun kurang menarik perhatian siswa. Siswa terlihat mudah bosan dan sangat pasif karena kurangnya rangsangan yang diberikan guru mengenai keaktifan siswa dalam belajar. Guru terbiasa menyampaikan materi dengan bercerita berdasarkan buku teks saja. Melihat fenomena yang terjadi di kelas VI SD Negeri 163087 Tebing Tinggi, peneliti mencoba untuk mengubah pembelajaran IPS agar lebih bisa memotivasi siswa untuk belajar. Salah satu cara yang dilakukan guru untuk meningkatkan motivasi siswa dalam belajar IPS adalah dengan menggunakan metode word square. Alasan peneliti menggunakan model pembelajaran word square yaitu dengan menggunakan model ini akan melatih sikap teliti siswa karena dengan model ini siswa tidak hanya mengetahui saja jawaban yang benar akan tetapi siswa juga di latih juga dengan mencari sebuah jawaban yang ada di kotak jawaban.

Word Square merupakan metode yang memadukan kemampuan menjawab pertanyaan dengan kejelian dalam mencocokkan jawaban pada kotak-kotak jawaban. Hampir sama dengan teka-teki silang tetapi bedanya jawabannya sudah ada namun disamarkan dengan menambahkan kotak tambahan dengan sembarang huruf atau angka penyamar atau pengecoh (Trianto, 2010:55). Adapun pendapat Mujiman (2007:140) bahwa model pembelajaran word square merupakan model pembelajaran yang memadukan kemampuan menjawab pertanyaan dengan kejelian dalam mencocokan jawaban pada kotakkotak jawaban". Jadi, dengan menggunakan model pembelajaran 
ini, siswa dimungkinkan untuk aktif dalam proses belajar dengan cara menjawab pertanyaan-pertanyaan melalui kotak-kotak jawaban, sekaligus model ini bermanfaat pula untuk melatih kejelian dan ketelitian siswa.

Word square merupakan salah satu metode pembelajaran yang dapat dipergunakan guru dalam mencapai tujuan pembelajaran. Instrumen utama metode ini adalah lembar kegiatan atau lembar kerja berupa pertanyaan yang perlu dicari jawabannya pada susunan angka acak pada kolom yang telah disediakan. Model pembelajaran word square merupakan serangkaian kegiatan yang dirancang untuk memungkinkan terjadinya proses belajar IPS pada siswa yang memadukan kemampuan menjawab pertanyaan dengan ketelitian dalam menjawab dan mencocokkan jawaban pada kotak beebentuk persegi berisi angka yang telah disediakan.

Dalam penerapan model pembelajaran word square terdapat beberapa langkah yang harus ditempuh. Langkah-langkah model pembelajaran word square adalah sebagai berikut: Pendidik menyajikan materi sesuai dengan topik bahasan yang dikaji melalui ceramah. Pendidik membagikan lembaran kegiatan berupa susunan huruf yang mengandung kata yang terdapat dalam materi ajar. Peserta didik memilih kata yang sesuai dengan soal yang diberikan, kemudian mengarsir huruf dalam kotak sesuai jawaban (Sani, 2013:249). Pendidik memberikan poin berdasarkan jumlah jawaban yang benar (Uno dan Nurdin, 2014 : 92).

Model pembelajaran ini juga tidak luput dari kelemahan. Ada beberapa kelemahan model word square menurut Lubis (2015 : 98-100) yaitu sebagai berikut: 1) Mematikan kreativitas siswa dalam belajar sebab siswa hanya menerima dari guru tanpa proses pencarian; 2) Membutuhkan kreativitas guru dan waktu yang lama dalam merancang lembar pertanyaan dan jawaban yang berupa kotak-kotak dan; 3) Terkadang siswa menganggap cara belajar ini hanya sekedar mainmain bukan belajar sesungguhnya.

$$
\text { Penelitian Apria }
$$
menyimpulkan bahwa rata-rata hasil belajar siswa menggunakan model pembelajaran Word Square berbantu media gambar kelas eksperimen mencapai 80,68 sedangkan nilai ratarata kelas kontrol yang diajar dengan menggunakan model pembelajaran Direct Instruction berbantu media gambar mencapai rata-rata 75,28. Jadi, dapat disimpulkan bahwa model pembelajaran Word Square berbantu media gambar berpengaruh signifikan terhadap hasil belajar IPA siswa kelas IV MIN 10 Bandar Lampung.

Tujuan dari penelitian ini adalah untuk meningkatkan hasil belajar IPS siswa kelas VI SD Negeri 163087 Tebing Tinggi tahun pembelajaran 2019/2020 melalui metode pembelajaran word square.

\section{METODE PENELITIAN}

Penelitiam tindakan kelas ini menggunakan metode deskriptif. Metode deskriptif adalah suatu metode 
penelitian yang ditujukan untuk menggambarkan fenomena-fenomena yang ada, yang berlangsung pada saat ini, atau saat yang lampau. Adapun subjek penelitian adalah siswa kelas II SD Negeri 163087 Tebing Tinggi semester 2 tahun pelajaran 2019/2020 dan sumber data yang digunakan adalah siswa dan teman sejawat.

Pada Penelitian tindakan kelas data yang dikumpulkan dapat berbentuk kuantitatif maupun kualitatif. Penelitian tindakan kelas tidak menggunakan uji statistik, tetapi dengan deskriptif. Data kuantitatif yang berupa nilai dianalisis dengan menggunakan analisis deskriptif komparatif yaiu membandingkan nilai tes kondisi awal, nilai tes setelah siklus I, dan II yaitu nilai dari hasil ulangan harian siswa kelas II pada siklus I dan II. Komponen pengajaran model word square yang sangat data kualitatif yang berupa observasi kegiatan guru, dan sisa serta data kuantitatif yangberupa nilai hasil ulangan harian siswa kelas II. Prosedur penelitian tindakan kelas iniada tahap perencanaan tindakan, pelaksanaan tindakan, pengamatan dan evaluasi, dan refleksi.

Masing-masing siklus terdiri dari dua kali pertemuan yaitu sebagai berikut: Perencanaan adalah tahap pengembangan rencana tindakan yang akan dilakukan secara teliti untuk meningkatkan apa yang telah dilakukan oleh peneliti. Peneliti menyusun rumusan masalah, tujuan dan membuat rencana tindakan, termasuk di dalamnya instrumen penelitian dan perangkat pembelajaran.

Tahap melakukan/pelaksanaan ini dilakukan untuk menerapkan rencana yang telah dibuat. Implementasi tindakan dimulai saat sebelum kegiatan dengan persiapan sebelum kegiatan dimulai, yaitu saat guru mengkondisikan siswa agar siap mengikuti pembelajaran.

\section{Siklus I}

Menyampaikan tujuan pembelajaran yang ingin dicapai sesuai dengan materi yang akan diajarakan. Peneliti menggali pengetahuan siswa dengan melakukan tanya jawab tentang materi ajar. Guru menyajikan dan menjelaskan materi ajar dan menerapkan metode word square dengan petunjuk pengerjaan LKS model word square agar siswa mengerjakan dengan konsisten dan teliti. Membahas bersama-sama jawaban LKS model word square dan memberitahukan siswa untuk memberikan skor pada setiap jawaban benar. Setelah itu guru menyimpukan pelajaran dan menutup pelajaran dengan tes ulangan harian.

\section{Siklus II}

Pada siklus II dilakukan hampir sama dengan siklus I namun ke arah yang lebih baik. Hal-hal yang dianggap kurang pada siklus I diperbaiki pada siklus II. Kegiatan yang perlu ditingkatkan pada siklus II adalah setelah siswa mengerjakan LKS metode word square, guru Memberikan instruksi bahwa waktu pengerjaan telah habis dan meminta 
siswa untuk menukar jawaban dengan dengan teman disebelahnya.

Pada tahap pengamatan mengamati segala jenis dan bentuk aktivitas siswa, lalu mencatatnya kepada lembaran observasi yang telah disediakan. Pada tahap ini dilakukan peneliti sendiri dan dibantu oleh pengamat.

Data yang diperoleh pada lembar observasi, dianalisis secara lebih dalam dan tajam pada siklus ke dua ini. Kemudian dilakukan refleksi atau perenungan. Pelaksanaan refleksi merupakan hasil observasi/ pengamatan peneliti pada saat melakukan observasi di kelas dan lingkungan sekolah yang bertujuan untuk mengevaluasi hasil tindakan yang telah dilakukan yaitu dengan menerapkan model pembelajaran word square. Tahapan ini dilakukan secara berkesimbungan sehingga ditemukan hasil yang optimal.

Instrumen yang digunakan dalam penelitian ini adalah pedoman observasi, test hasil belajar dan kegiatan belajar mengajar. Data aktivitas belajar dan kendala yang dihadapi selama proses pembelajaran dikumpulkan melalui observasi (lembar observasi terlampir). Data hasil observasi, dan data hasil wawancara yang jenis datanya berupa pernyataan-pernyataan, dianalisis dengan menggunakan teknik analisis statistik deskriptif.

Metode pengumpulan data penelitian ini adalah tertulis dan observasi. Pemberian tes digunakan untuk mengukur tingkat ketuntasan hasil belajar peserta didik setelah diterapkan model pembelajaran kooperatif tipe Word Square. Penelitian ini dikatakan berhasil apabila siswa telah memperoleh nilai ketuntasan secara klasikal minimal $80 \%$ dari jumlah siswa dengan rumus sebagai berikut:

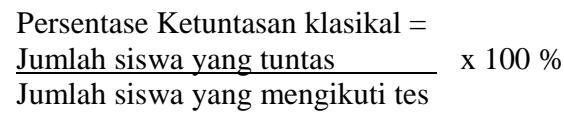

\section{HASIL PENELITIAN DAN PEMBAHASAN}

Hasil data penelitian diuraikan berdasarkan siklus-siklus tindakan pembelajaran. Langkah awal yang dilakukan oleh peneliti adalah mengidentifikasi masalah ke sekolah peneliti. Setalah itu peneliti mencari hasil belajar (prasiklus) peserta didik dari daftar nilai yang ada di SDN 163087 Tebing Tinggi. Pada pelaksanaan pra siklus ini guru masih menggunakan metode pembelajaran konvensional seperti metode ceramah, yaitu belum menggunakan metode word square. Berdasarkan tabel di berikut dapat kita lihat kemampuan siswa dalam menjawab soal-soal pre test tergolong sangat rendah. Hal ini dapat dilihat pada pra tindakan dari 32 siswa dalam satu kelas, terdapat 15 siswa yang belum mencapai KKM.

Hasil penelitian tindakan kelas setiap siklusnya dengan penerapan metode pembelajaran word square pada mata pelajaran IPS kelas VI SD Negeri 163087 Tebing Tinggi dapat dilihat pada Tabel 1 yaitu sebagai berikut: 
Syahrial Nasty : Upaya Meningkatkan Hasil ...

Tabel 1. Peningkatan Hasil Belajar

\begin{tabular}{c|c|c|c}
\hline \multirow{2}{*}{ Parameter } & \multicolumn{3}{|c}{ Peningkatan Hasil Belajar } \\
\cline { 2 - 4 } & Pra siklus & Sikus I & Siklus II \\
\hline $\begin{array}{c}\text { Nilai x } \\
\text { ulangan } \\
\text { harian }\end{array}$ & 68,5 & 71,4 & 72,6 \\
\hline $\begin{array}{c}\text { Jumlah } \\
\text { Siswa }\end{array}$ & 17 & 24 & 29 \\
\hline $\begin{array}{c}\text { Persentase } \\
\text { Aktivitas }\end{array}$ & 72 & 77,4 & 81,2 \\
Siswa (\%) & & 75 & 90,62 \\
\hline $\begin{array}{c}\text { Persen } \\
\text { Ketuntasan } \\
(\%)\end{array}$ & 53,12 & & \\
\hline
\end{tabular}

Hasil analisis pengamatan peneliti dari tindakan pra siklus, siklus I dan siklus II pada Tabel 1 terjadi peningkatan hasil belajar siswa. Pada pra siklus terdapat 15 siswa yang belum mencapai KKM dalam satu kelas. Pembelajaran pada saat pra siklus hanya berlangsung satu arah saja, di mana guru menyampaikan materi pembelajaran di depan kelas, kemudian peserta didik mendengarkan materi yang disampaikan oleh guru. Pada Tabel 1 dapat dilihat terjadi peningkatan jumlah siswa yang lulus KKM dari 17 siswa yang tuntas belajar pada pra siklus menjadi 24 siswa yang tuntas pada siklus I metode pembelajaran word square pada siswa kelas VI SD Negeri 163087 Tebing Tinggi.

Pada pembelajaran siklus I guru memberikan penjelasan secara singkat mengenai materi, kemudian guru membagikan lembar kegiatan kepada semua peserta didik lembar kegiatan yang berbentuk Word Square yang mana peserta didik fokus mendengarkan pertanyaan guru dan peserta didik menjawabnya dengan cara mencari dan mengarsir kotak sesuai dengan jawabannya. Hasil belajar siklus I diperoleh nilai rata-rata kelas 71,4 dengan nilai maksimal 90 dan nilai minimal 60. Persentase aktivitas belajar siswa sebesar 77,4 \% . Sedangkan ketuntasan belajar siswa pada siklus I meningkat menjadi $75 \%$. Terdapat pengaruh yang positif dalam penggunaan metode Word Square terhadap hasil belajar IPS materi mendeskripsikan gejala (peristiwa) alam yang terjadi di Indonesia dan negara tetangga pada siswa kelas VI SDN 163087 Tebing Tinggi tahun pelajaran 2019/2020.

\section{Pembahasan}

Dari penjelasan di atas menunjukkan bahwa pemahaman dan hasil belajar siswa setelah melalui tindakan dengan menggunakan metode pembelajaran word square mengalami peningkatan setiap parameternya meskipun masih belum sesuai dengan presentase ketuntasan klasikal yang ditetapkan $\quad(\geq 80 \%)$, sehingga perlu dilakukan kembali perbaikan pembelajaran pada siklus II yang mungkin dapat mencapai presentase ketuntasan klasikal yang ditetapkan. Pembelajaran pada siklus II difokuskan pada kesulitan yang dialami siswa dalam mempelajari materi siklus I. Selain itu peneliti akan memberikan reward kepada siswa yang apabila kelompok tersebut dapat mempersentasikan hasil diskusi didepan kelas dengan baik dan jelas. Jadi, pembelajaran pada siklus berikutnya tidak akan mengulang keseluruhan pembelajaran pada siklus 
I, tetapi melakukan perbaikan dan pembenahan sesuai kebutuhan siswa.

Hal-hal yang dianggap kurang pada siklus I diperbaiki pada siklus II dan yang dianggap baik dipertahankan pada siklus II. Dalam perbaikan ini diharapkan siswa menjadi lebih aktif dalam proses pembelajaran dan hasil belajar siswa dapat meningkat sesuai target yang akan dicapai. Setelah dilakukan refleksi pada siklus I, terjadi peningkatan aktivitas dan hasil belajar pada siklus II. Pada siklus II diperoleh aktivitas belajar siswa meningkat menjadi 81,2 dengan ketuntasan belajar siswa sebesar 90,62 \% . Hal ini berarti strategi pembelajaran yang digunakan dapat memberikan kesempatan bertanya kepada siswa, membimbing siswa untuk konsisten dan teliti, serta mengarahkan siswa untuk menarik kesimpulan.

Pada siklus II yang telah dilaksanakan dapat dikatakan juga bahwa langkah-langkah kegiatan pembelajaran yang dikembangkan telah sesuai dengan metode pembelajaran word square yang disusun sesuai indikator,langkahlangkah pembelajaran word square ditulis dalam RPP, urutan kegitan langkah-langkah pembelajaran yang logis yang memuat peran guru dan peran siswa, serta dapat dilaksanakan oleh guru.

Berdasarkan data yang diperoleh selama proses pembelajaran berlangsung bahwa peneliti melihat respon siswa pada saat mengikuti proses belajar mengajar sudah baik, dikarenakan ketika peneliti menjelaskan materi didepan kelas tidak ada lagi siswa yang ribut atau bercerita, melaikan semua memperhatikan dan mendengarkan peneliti. Hal tersebut terbukti dari 32 siswa terdapat 29 orang yang mampu mencapai nilai ketuntasan belajar. Dapat dikatakan bahwa penggunaan metode word square melibatkan pembelajaran aktif pada siswa karena Model pembelajaran word square dapat mendorong pemahaman siswa terhadap materi pembelajaran, menciptakan suasana yang menyenangkan karena pembelajarannya berupa permainan, melatih siswa disiplin,merangsang siswa untuk berfikir aktif karena model pembelajaran ini mampu sebagai pendorong dan penguat terhadap materi pembelajaran. Hal ini sesuai dengan pendapat Heriawan (2012 :125) Bahwa metode word square merangsang siswa untuk berpikir efektif. Selain itu, Proses pembelajaran dengan model pembelajaran word square mendorong pemahaman siswa terhadap materi pelajaran.

Model pembelajaran word square merupakan serangkaian kegiatan yang dirancang untuk memungkinkan terjadinya proses belajar IPS pada siswa yang memadukan kemampuan menjawab pertanyaan dengan ketelitian dalam menjawab dan mencocokkan jawaban pada kotak beebentuk persegi berisi angka yang telah disediakan.. Maka dari itu metode word square terbukti meningkatkan hasil belajar siswa dari pra siklus, siklus I hingga siklus II. Berdasarkan hasil temuan dan analisis 
data penelitian maka dapat disimpulkan bahwa penggunaan model pembelajaran word square dapat meningkatkan hasil belajar IPS pada siswa kelas VI SD Negeri 163087 Tebing Tinggi tahun pelajaran 2019/2020.

\section{SIMPULAN}

Kesimpulan dari hasil penelitian diatas adalah penerapan metode word square dapat meningkatkan aktivitas dan hasil belajar siswa mata pelajaran IPS di kelas VI SD Negeri 163087 Tebing Tinggi tahun pelajaran 2019/2020. Hal tersebut dapat dilihat dari peningkatan persentase ketuntasan belajar siswa pada siklus I (75\%), siklus II $(90,62 \%)$. Peningkatan hasil belajar siswa menncapai tingkat ketuntasan belajar secara klasikal berhasil terjadi pada siklus II.

\section{DAFTAR RUJUKAN}

Heriawan, Adang. 2012. Metologi Pembelajaran Kajian Teoritis Praktis. Banten: Perum Bumi Baros Chasanah.

Lubis, Effi Aswita. 2015. Strategi Belajar Mengajar. Medan: Perdana Publising

Mujiman. 2007. Model Pembelajaran Word Square. Jakarta: Raja Grafindo Persada

Sani, Ridwan Abdullah. 2013. Inovasi Pembelajaran. Jakarta: Bumi Aksara

Sapriya. 2009. Pendidikan IPS. Bandung: Rosda Karya.

Susanto, Ahmad. 2013. Teori Belajar Dan Pembelajaran Di Sekolah
Dasar. Jakarta: Kencana Prenada Media Group. Trianto. 2010. Model Pembelajaran Terpadu Konsep, Strategi Dan Implementasi Dalam Kurikulum Tingkat Satuan Pendidikan. Jakarta: Bumi Aksara.

Uno, Hamzah dan Nurdin Mohamad. 2014. Belajar dengan Pendekatan Paikem: Pembelajaran Aktif, Inovatif, Lingkungan, Kreatif, Efektif, Menarik. Jakarta: Bumi Aksara. 